\title{
Sivert Angel \\ Chapter 6 \\ Topos and Topography: \\ Jerusalem in the Memory of Christian III, \\ King of Denmark-Norway
}

This chapter discusses the relevance of the Jerusalem code as political legitimization strategy at the introduction of the Reformation in Denmark and Norway. It does so by an investigation of the rhetorical use of Jerusalem in the funeral orations for Christian III. The concept of place, or "topos", a central part of rhetorical theory of that time, was meant to direct the invention process of a speech by pointing the speaker to a field where he might find authoritative and convincing arguments. This chapter employs the topos concept to analyze the speeches' rhetorical strategies and Jerusalem's role in them. The second part of the analysis establishes connections between the rhetorical strategies and concrete descriptions of places, primarily of Christian III's kingdom, Copenhagen and Denmark-Norway, descriptions which in this chapter are labelled as "topography". This chapter uses Jerusalem to describe early Danish knowledge culture and its role in religious politics by investigating, first, how Jerusalem might have played a role in lending authority to these speeches and, secondly, how it contributed to the official memory of the King.

\section{Introduction}

King Christian III of Denmark and Norway (1503-59) is a central figure in DanishNorwegian history. With his rule, civil war ended and the reformation was introduced, making Christian III head of the Danish-Norwegian church. By dynastic relations and his status as a German prince, he was closely tied to German Lutheran sovereigns. His church order was written with the help of German theologians, and a majority of the theology professors at his university had studied in Germany. ${ }^{1}$ It is no coincidence, therefore, that funeral speeches for him have stylistic features similar to speeches in

1 Martin Schwartz Lausten, "Die Universität Kopenhagen und die Reformation," in University and Reformation: Lectures from the University of Copenhagen Symposium, ed. Leif Grane (Leiden: Brill, 1981).

Sivert Angel, Associate Professor in Practical Theology and Church History, Faculty of Theology, University of Oslo, Norway

Ә Open Access. ( 2021 Sivert Angel, published by De Gruyter. (c) BY-NC-ND This work is licensed under the Creative Commons Attribution-NonCommercial-NoDerivatives 4.0 International License.

https://doi.org/10.1515/9783110639452-007 


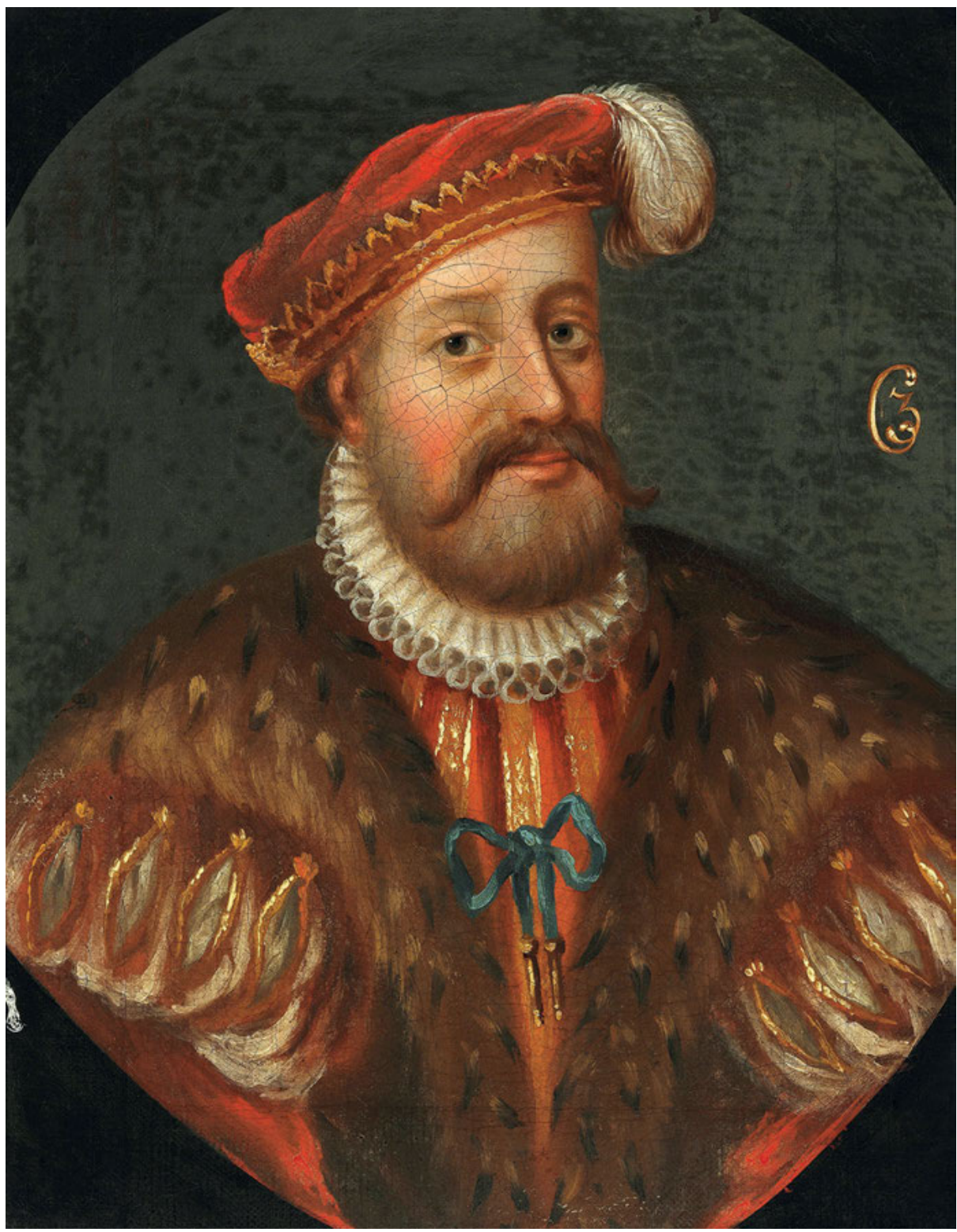

Fig. 6.1: Portrait of Christian III (1503-59), King of Denmark and Norway, Duke of Holstein and Schleswig. 
Lutheran Germany. Christian III died after twenty-five years of relatively peaceful and prosperous rule. $^{2}$

The King's authority in matters of religion is a central concern in the orations for him, with good reason. The church was subjugated under his rule and church treasures confiscated. The King had not been without opponents in his proceedings, as revealed in the orations' portrayal of the King's road to power and his victory in the civil war. On his death, there would most probably have been conflicting views on how this was to be valued and remembered, an ambiguity echoed in later historiography's discussions of whether the King protected the true church or simply removed it and replaced it with the state, and whether he was elected by the council, or if he, assisted by German mercenaries, had forced the council to accept him. ${ }^{3}$ The theological legitimacy of the King's role in the church would have been vital for the general acceptance of his authority. Therefore, the motif of the King as protector of church and religion, as cura religionis, shall be a central interest in the analysis of the speeches. We shall proceed in this by a rhetorical analysis. In early modern theory, rhetoric and dialectic were seen as closely connected. ${ }^{4}$ Therefore, the question of the form and content of speech was not simply a question of communication, but also of truth. For something to be used in a speech, it had to be proper knowledge. Rhetorical analysis may therefore say something about how speeches grounded their claims, as well as about the knowledge culture to which they belonged. This chapter will follow this path in investigating Jerusalem's role in the legitimization of religious authority in reformation DenmarkNorway.

The two most influential of the many speeches presented to commemorate the King were royal physician Jacob Bording's sermon at the funeral in Odense Cathedral and theologian Niels Hemmingsen's speech at the University of Copenhagen on the day of his funeral. Both orators had studied in Germany - theology professor Hemmingsen was one of Philip Melanchthon's (1497-1560) favorite students, ${ }^{5}$ while the Dutch royal physician Bording had read Melanchthon and had studied with him for a shorter period. It is no coincidence therefore, that both orations relate to a rhetorical tradition shared with protestant Germany. In this chapter, we shall analyze the two speeches to see how Jerusalem and the Jerusalem code are utilized within sixteenth-century Lutheran rhetoric to serve the memory needs of the newly established Lutheran empire, Denmark-Norway.

2 Birgitte Bøggild Johannsen, “Ars Moriendi More Regio: Royal Death in Sixteenth Century Denmark,” Journal of Early Modern Christianity 1, no. 1 (2014): 69-70.

3 Steinar Imsen, Da Reformasjonen kom til Norge (Oslo: Cappelen Damm, 2016); Øystein Rian, Sensuren i Danmark-Norge. Vilkårene for offentlige ytringer 1536-1814 (Oslo: Universitetsforlaget, 2014), 331.

4 Peter Mack, A History of Renaissance Rhetoric 1380-1620 (Oxford: Oxford University Press, 2013).

5 Martin Schwartz Lausten, Niels Hemmingsen. Storhed og fald (Copenhagen: Anis, 2013), 13-20. 


\section{Method}

\section{Genre: Place in Protestant Funeral Orations}

The speeches belong to a genre that rose out of Lutheran theology and ritual practice during the sixteenth century. ${ }^{6}$ Prayers for the dead were abolished from funerals and the deceased instead entered the ritual via the sermon as examples of the biblical message preached. ${ }^{7}$ The genre could serve memory politics by combining a religious message with descriptions of the deceased to extract moral impulses and establish an official memory. Funeral orations for rulers could combine remembrance with governance, when the official memory of a ruler and his rule also stated the premises for how the subjects should relate to the new ruler and to the government in general. ${ }^{8}$ The subjects who were addressed in the funeral speeches for Christian III would rarely have met the King in person, but were related to him by living in his kingdom. Therefore, the construction of royal memory that took place in the funeral orations did not simply portray the King's person, but also his rule and the place that was his.

The primary place in the orations is the King's place, the place that was inseparable from his person and his memory, namely Copenhagen and Denmark (Fig. 6.2). However, the way this place is combined rhetorically with other places indicates how these orations take part in politics. The concept of topos from contemporary rhetorical theory will be employed to investigate how normative descriptions, topographies, of the King's place are established.

The precise borders for the genre are not easily drawn. On the occasion of the death of a sovereign, multiple funeral orations could be ordered, to be presented at several stages on the sovereign's final journey from death bed to burial. They would be presented in churches on the route, but often also ordered to be read in many of the country's churches, as well as in schools and universities. ${ }^{9}$ The most classic version is the sermon presented at the funeral itself, but also funeral orations presented in other services belong to the genre, as those that were written only for print, as well as speeches presented in other contexts that resemble funeral sermons by the way they combine a Christian message with a biographical account. In my material, Jacob Bording's speech belongs to the first category, whereas Niels Hemmingsen's belongs to the last.

6 Corneliea Niekus Moore, Patterned Lives: The Lutheran Funeral Biography in Early Modern Germany (Wiesbaden: Harrassowitz, 2006).

7 Berndt Hamm, "Normierte Erinnerung: Jenseits- und Diesseitsorientierung in der Memoria des 14. bis 16. Jahrhunderts," Jahrbuch für biblische Theologie 22 (2007).

8 Sivert Angel, The Confessionalist Homiletics of Lucas Osiander (1534-1604) (Tübingen: Mohr Siebeck, 2014), 67-138.

9 Johannsen, “Ars Moriendi More Regio: Royal Death in Sixteenth Century Denmark," 70; Angel, The Confessionalist Homiletics of Lucas Osiander (1534-1604), 68-96. 


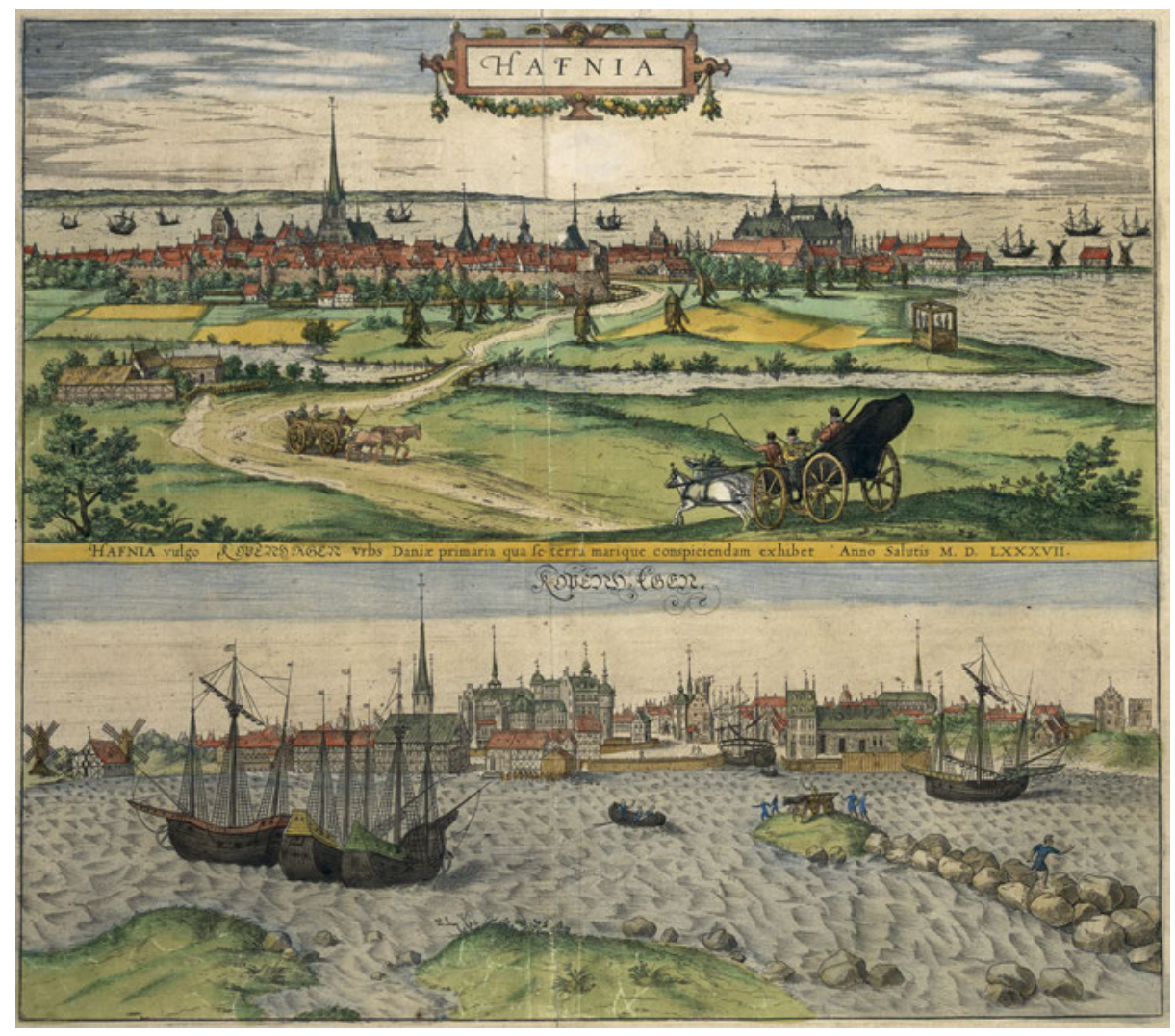

Fig. 6.2: Georg Braun, Frans Hogenberg, and Simon Nouellanus, Hafnia Kopenhagen. 1587. Engraving. From Civitates orbis terrarum (1576-1600), vol. 4.

\section{Topos in Rhetorical Theory}

Topos was a central concept in early modern rhetoric, and will be the main analytical concept in this chapter. Topos brought the concept of place into speeches on different levels and could play several roles in an argument. Rhetoric theory was held in high regard among sixteenth-century theologians, and training in these skills was part of basic university education. ${ }^{10}$ Since it taught how one should employ language forms in order to achieve a speech's goal, the theory is valuable for historical study. When argumentative patterns, figures, and speech elements recommended by rhetorical theory are

10 Mack, A History of Renaissance Rhetoric 1380-1620; Lausten, Niels Hemmingsen. Storhed Og Fald, 21-22. 
recognized in historical speeches, they may reveal how the concrete speeches aimed at persuasion.

Philip Melanchthon was not only the most influential author on rhetoric of his time and the primary theorist for Hemmingsen and Bording, but the concept topoi or loci played an important role in his manuals, with Melanchthon drawing on a long tradition when he employed this concept. It had its roots in Aristotle's Dialectics and Rhetoric, which had been a part of university curricula throughout the Middle Ages, and which had influenced early modern theory by a line of interpretations and adaptions. It is believed that topos was also part of a rhetoric tradition prior to Aristotle, where place had been recognized as a potent tool for aiding the mind's memory of difficult lines of thought, by coupling thought movements to visualized places. It was also recognized that tying an argument to a place could lend it power to convince by moving thoughts and feelings more effectively than purely abstract expressions. ${ }^{11}$

Aristotle had used the term "place" to signify valid and convincing patterns of argument in a discussion, such as syllogisms, as tools for those training in discussion or speech. The places referred to groups of enthymems, meaning argumentative sentences. Aristotle might have chosen the term place because he envisioned a discussion as a terrain seen from above, with arguments existing in a strategic space, where certain ways of moving forward offered themselves as viable, while others were blocked. To argue well, one should first examine the terrain and see which angle the opponent could be attacked from. The knowledge of topoi aided the speaker by allowing him to see fields of knowledge from above so that possible connections and patterns of arguments were revealed. ${ }^{12}$

Though Aristotle regarded topics as a universal and formal form of knowledge belonging to both logic and rhetoric, ${ }^{13}$ in his Rhetoric he seems to admit that there are specific topoi useful for certain genres of speech - in other words, that they connect to specialized knowledge with a material content, such as laws, witnesses, admittances brought forth under torture, and oaths. ${ }^{14}$ Cicero, the favorite author on rhetoric in university curriculums throughout the Renaissance, ${ }^{15}$ developed this slight tendency in his understanding of topos. He defined topics as the art of finding arguments, and defined topos as arguments' dwelling place, sedes argumenti - the place where valid and authoritative arguments are to be found. It was not simply a general concept for formal patterns, but included the thematic and material content of an argument, so that both the argument's res and its verborum were to be found in the topos.

11 Klaus Ostheeren, “Topos,” in Historisches Wörterbuch der Rhetorik, eds. Gert Ueding and Walter Jens (Tübingen: Niemeyer, 2009), 631.

12 Tim Wagner, “Topik," in Historisches Wörterbuch der Rhetorik, eds. Gert Ueding and Walter Jens (Tübingen: Niemeyer, 2009), 607.

13 Wagner, "Topik," 608.

14 Aristoteles, Retorikk (Oslo: Vidarforlaget, 2006), 177-88. (II, 23); Wagner, “Topik,” 612.

15 Mack, A History of Renaissance Rhetoric 1380-1620. 
Continuing from Cicero's concept, Boethius saw topos as the place where arguments were found that suited a certain question, and Thomas Aquinas defined topics as describing the sources for theological argument, namely scripture, church fathers, reason, and philosophers. Topoi were not simply concepts and sentences useful in a certain discussion, but concepts and sentences that could be presupposed. ${ }^{16}$

Philip Melanchthon employs this tradition in his writings on rhetoric. Günter Franck has argued that Melanchthon employed topos in a way that combined the two strands of tradition. Topos is the place where an argument is to be found, but also a method for finding good arguments; the process of invention, abstraction, and construction of principles. ${ }^{17}$ Niels Hemmingsen had published a book on method, De methodis libri duo, ${ }^{18}$ four years prior to his funeral oration for Christian III, which followed Melanchthon quite closely in employing the concept of locus as indicating the sources for an argument as well as its legitimate form. It gave basic principles for scriptural interpretation and the design of arguments in a sermon. Like Melanchthon he saw loci as a method for abstracting sentences from a narrative text that could be condensed into categories. ${ }^{19}$ However, even though Hemmingsen based his method on Melanchthon, commentators have claimed he went further in seeing the concept of topos as a means for proof, and not merely as a principle for ordering and understanding a given material. ${ }^{20}$

Early modern rhetorical theory indicates that orators might employ place in two ways, and this chapter will analyze the two funeral orations using these two viewpoints: firstly, it will employ the Aristotelian concept of topos to extract the patterns of argument that appear in the speeches, and secondly, it will employ Cicero's locus concept to describe the dwelling places for arguments which the two funeral orations refer to and extract arguments from.

A third and final part of the analysis continues from the traditional meaning of rhetorical place and asks whether rhetorical places produce certain descriptions of concrete places or topographies. Topography is a term seldom used in rhetorical theory, and the parts of speeches that are treated as topography in this analysis would probably be categorized as exempla in Aristotelian rhetoric. They describe places as they appear in narrations, encompassing political and religious reality.

16 Wagner, "Topik"; Günter Frank, "Wie kam die Topik in die Theologie? Topik als Methode der Dogmatik bei Philipp Melanchthon und Melchior Cano," in Hermeneutik, Methodenlehre, Exegese: Zur Theorie der Interpretation in der frühen Neuzeit, eds. Günter Frank and Stephan Meier-Oesen (Stuttgart: Frommann-Holzboog, 2011).

17 Frank, "Wie kam die Topik in die Theologie?".

18 Niels Hemmingsen, De Methodis, (Wittenberg, 1559).

19 Frank, "Wie kam die Topik in die Theologie?".

20 Hemmingsen, De Methodis; Tarald Rasmussen, "Rationalität und Bibelauslegung in Niels Hemmingsens De Methodis (1555)," in Reformation und Rationalität. Refo500 Academic Studies, eds. Herman J. Selderhuis and Ernst-Joachim Waschke (Göttingen: Vandenhoeck \& Ruprecht, 2016). 
These descriptions of place appear within an argumentative pattern controlled by place in its rhetorical sense, topos. Rhetorical theory thus offers an analytical perspective for the description of concrete place. Topos offers the optics, a point of view that enables a description of topography's rhetorical function. Through these tools, this analysis will shed light on the significance of the Jerusalem code at the time when the memory of Christian III was established.

\section{Analysis}

Before we search for Jerusalem in descriptions of places, we shall investigate the topoi the orators employed to find convincing ways of arguing. Both speeches to be analyzed transcend their original situation and became models for many other sermons and speeches presented around the country in the weeks following the funeral, such as Hans Thomissøn's sermon presented to the school in Ribe, which was based on Hemmingsen's oration. ${ }^{21}$ Still, although the two speeches were presented on the same day and employed widely in the official remembrance of the King, they are clearly different, probably because of their different genres. In rhetorical theory, genre was controlled by the occasion for a speech, and a speech's recommended way of arguing was to some extent controlled by its genre. Jacob Bording oration was preached as a sermon at the King's funeral in Odense cathedral and therefore relates to homiletic theory. However, homiletic theory also relied on basic rhetorical concepts. In Melanchthonian theory, it is not primarily the form of argument that distinguishes the different genres, but rather where they find their authoritative arguments. As a sermon, Bording's speech had the interpretation of scripture as its basis, whereas Hemmingsen's speech, which was presented to the university college according to the rules of a classical tributary oration, could employ a different basis for its argument. Their choices of the basis for argument will be discussed in the next section. Here we shall firstly investigate the form of argument in the two speeches, for even though theory did not prescribe different forms of argument for the two genres, there are significant differences between the two speeches in this respect.

21 Johannsen, “Ars Moriendi More Regio,” 70; Ioanne Thoma Ripensi, “Alia Oratio De Illustrissimo Principe ac Domino, Domino Christiano III, Rege Daniae \& Noruegiae, \& C.," in Tröstliche Historia vom seligen Abschied des Durchleuchtigen (. . .) (1559). 


\section{Topics 1 - Argumentative Patterns}

Bording's sermon starts with a retelling of the story about King Hezekiah from 2 Kgs 20. Together with King Josias, the story of King Hezakiah was a favorite in Lutheran funeral sermons, since it told about a pious King who had rid the country of idolatry, instituted a pure cult, protected the church, and thereby saved the country. After two pages, the account of King Christan's life is introduced as one that will show how the image of the holy King from Old Testament history finds its expression in the life of King Christian:

The story of this most holy King, which is clearly and completely written in the Holy Scriptures, shall here be briefly summarized, in order to express how his image in every way resembles our most excellent King Christian III. ${ }^{22}$

King Christian's biography is then related along the same lines as the story of King Hezekiah. Four moments in the life of King Hezekiah form the headlines for the story of King Christian's life; his piousness, his upholding of peace, his studies, and his blessed ending, before the coupling of the two Kings is completed in a final delivery of King Christian to the community of the heavenly church with Hezekiah, David, Josiah, and Johann Friedrich; three Old Testament kings and one Lutheran Saxon prince:

Therefore our first and most excellent King, who was a Hezekiah of our age, especially honorable and distinguished, has been moved from this miserable and mortal life to God and the blessed community of all the Saints. Though it is sad and gives bitter sorrow, he now rests from us according to his great longing, a rest he enjoys sweetly in the community of the heavenly church, where he lives with Hezekiah, David, Josias, Johann Friedrich, and other pious princes. $^{23}$

Bording argues inductively in his sermon. He does not deduce his arguments from sentences, such as enthymems or rules, but begins with the examples and allows them to point to principles. The example of Hezekiah relates how the temple was cleansed from idolatry and proper worship was enforced, resulting in progress and prosperity. The next part of this example tells about the Assyrian siege of Jerusalem, and how Hezekiah placed his trust in God and who then intervened by sending a

22 "Hanc sanctissimi regis historiam, sacrarum literarum monumentis copiose satis explicatam, breuiter ac summatim, itdeo recensui, quia expressam atque omnino similiam imaginem eius nuper vidimus, in optimo rege nostro CHRISTIANO III.” Jacob Bording, Oratio de obitu serenesis: principis Christiani III. Daniae \& Noruegiae Regis \& C (Copenhagen: Hans Barth, 1559), Aiii.

23 "Ita rex optimus ac praestantissimus, huius aetatis nostrae Ezechias, regum quem omnium qui nunc sunt, praecipuum decus \& Gloria, ex hac misera \& mortali vita, ad Dei \& sanctorum omnium beatissimum coetum, translatus est: tristem quem \& acerbum luctum, magnum quem sui desiderium, nobis reliquit: Ipse autem fruitur dulci consuetudine coelestis ecclesiae, viut quem cum Ezechia, Dauide, Iosia, Ioanne Friderico, \& similibus piis principibus.” Bording, Oratio de obitu serenesis: principis Christiani III. Daniae \& Noruegiae Regis \& $C, D$. 
deadly angel against the Assyrians, thereby protecting the city. The example points to two rules or ethymems, namely that he who cleanses the cult and institutes true worship will experience progress and he who places his trust in God will be protected. Bording then narrates King Christian's life and reign as resembling that of Hezekiah. As a reformation King he removed catholic idolatry and instituted a pure and solid church, and as a pious King he listened to God's advice and experienced progress in his kingdom and protection from enemies. The argument is that since Christian conforms to Hezekiah's example, the same rule was relevant during his reign.

However, if one takes a step back from this argument and observe the two examples together, another rule may be recognized as structuring the first rule. It is the rule of typology, which traces archetypes to prototypes, or connects them as types and anti-types, and, in theology, sees them as acting within the course of salvation history. It states that he who resembles a biblical role model may expect the same course of events to take place in his life, and that a reign and a kingdom resembling a biblical role model underlay the same dynamics as those described in the bible. In other words, it is a rule saying that history repeats itself. ${ }^{24}$

The pattern of argument in Bording's speech presents biblical Kings and kingdoms as types that impress their mark on contemporary figures and society in a way that makes history predictable. It belongs to a topos where narrative elements are combined in an argument through the use of a typology which allows the contemporary example to appear as an imprint of an Old Testament example. The sermon shares this topos with many contemporary Lutheran funeral sermons for German princes, which also rely on the same typological pattern of argument and used the same Old Testament kings - typically David, Hezekiah, and Josiah - as their point of departure. ${ }^{25}$ Theology professor Niels Hemmingsen's speech was presented to a learned audience at the University in Copenhagen and would not have been a part of a service, but through its clear theological message it nonetheless resembles a sermon.

Hemmingsen starts his speech by addressing the occasion for the speech, namely the great sorrow involved in losing a great King, and claiming that the sins of the subjects had occasioned this loss as a punishment from God. He then declares the King as saved and as being welcomed to a heavenly existence by the prototypical protestant rulers David, Josiah, and Hezekiah, ${ }^{26}$ Thus, Hemmingsen tied Christian III to the great kings of biblical history, but in his argumentation they came to play yet another role. Hemmingsen states that the goal for his oration is to

24 Rudolf Suntrup, “Typologie,” in Historisches Wörterbuch der Rhetorik, ed. Gert Ueding and Walter Jens (Tübingen: Niemeyer, 2009).

25 Angel, The Confessionalist Homiletics of Lucas Osiander, 67-138; Moore, Patterned Lives, 211-75. 26 Niels Hemmingsen, Funebris oratio in memoriam ... regis Danorum \& C. Christian Tertii (Copenhagen: Christophorum Barth, 1559), Aii. 
present King Christian as an example and a pattern of virtue, both to the subjects and to his successor King Friedrich II. ${ }^{27}$

He then presents the following main enthymem for the speech: according to the wise men of ancient times, a good regent must embody three virtues, namely wisdom with regard to secular things, zeal for God's church, and virtue and a Christian spirit in the things that concern his own house. ${ }^{28}$ These three virtues then structure the rest of the speech.

If one applies the Aristotelian concept of topos to Hemmingsen's sermon, a different terrain of argument appears. The sections treating the three virtues are dealt with in succession and are each introduced with their own enthymem, derived from representatives of the wise men of old, the majority from the antique tradition. Accounts of Christian III's life serve as examples that confirm the validity of the enthymems, while at the same time portraying Christian's rule as exemplary and conducted in accordance with universal rules (Fig. 6.3). ${ }^{29}$ Though Christian is the most prominent example in the speech, several other examples are mentioned that resemble him and confirm the universal rules in the same manner as him, such as Moses, David, Salomon, Hezekiah, Josiah, Cyrus, Theseus, Alexander the Great, Hiero, and Theodosius. Thus, examples are also central in Hemmingsen's speech, but here they are part of a deduction where they prove rules. The examples are not expressions of the same image, but complement each other in exemplifying different aspects of rule.

Thus, the following different fields of argument reveal themselves: in Bording's typology, the examples appear as fixed, both to each other and to history, while Hemmingsen's examples seem more arbitrary and flexible, chosen because of their ability to illustrate a rule. They could in principle have been substituted with other examples. His enthymems are firm and abstract, whereas the examples that illustrate them are flexible.

\section{Topics 2 - The Arguments' Dwelling Places}

The next aspect of the topos concept that I shall employ in the analysis resembles a common understanding of place - topos as the dwelling places for arguments.

27 “. . . adeo ut exemplar virtutum omnium heroicarum \& communium illustre statui possit." Hemmingsen, Funebris oratio in memoriam . . . regis Danorum \& C. Christian Tertii Aiii.

28 "Tria itaque in uniuersum sunt, quorum curam pium principem habere oportere, sapientes olim censuerunt, ac hodie pii omnes veterum censuram approbant. Horum primum est societatis civilis prudens gubernatio. Alterum Ecclesiae conseruande studium. Tertium proproae domus honesta \& sancta administratio." Hemmingsen, Funebris oratio in memoriam . . regis Danorum \& C. Christian Tertii, Aiii.

29 Hemmingsen, Funebris oratio in memoriam . . . regis Danorum \& C. Christian Tertii, Aiii-Cii. 
I shall investigate whether Jerusalem plays a role on this level of the speeches by asking where Hemmingsen's and Bording's orations find their premises.

Bording's place is easy to define. He finds his premises in the bible and its account of history, as the history of the people of God. This history lends power to his typology and the analogous coupling with the examples it comprises. This coupling requires narration and therefore also place, and the nature of this place is decisive for the strength of the typology it serves. In this sense of topos, the place in Bording's sermon is not only the bible, or Israel's history, but Jerusalem itself. It is in Jerusalem that idolatry is abolished, a pure cult reinstalled, priests and Levites summoned, and treasures collected to finance temple service. Moreover, it is Jerusalem that is protected from the Assyrians by God's miraculous intervention, as a result of King Hezekiah's attentiveness to God's advice. ${ }^{30}$

According to the rules of rhetoric, an orator should choose arguments from dwelling places that are convincing to his audience. Bording would have assumed that the congregants present in church at the King's funeral would see themselves as belonging to the people of God and as tied to Israel's history and Jerusalem as a model city. In this sense, Bording's topos is a religiously significant place, envisioned geographically and embedded in the shared historical narrative of salvation history. It serves analogous connections that give elaborate prescriptions for a King's rule. However, in this way, the effectiveness of the oration's topos presupposes adherence to this understanding of history, which is to a faith that has church as its place. This rhetorical logic is common to many Lutheran funeral sermons and might be regarded as a genre convention.

The dwelling place for Hemmingsen's arguments, on the other hand, is barely expressed spatially. His enthymems are drawn from a long succession of sources: Salomon, Homer, Cicero, Xenophon, David, Solomon, Euripides, Seneca, Isocrates, Aristotle, Plato, Moses, and Paul. For Aristotle's part, Hemmingsen explicitly mentions that he did not know true religion, but states that this fact strengthens the claim that care for religion should be of primary concern to a ruler. The indicated topos appears as a very wide field and can hardly be described as a place. Athens is mentioned a couple of times, but since the sources for argument are tied to different lands and cities and are not connected by a common historical narrative, their place cannot be described spatially. The few times Jerusalem enters Hemmingsen's speech, it is always implicitly, namely as the place for the rule of David and Solomon, and always on the level of examples or illustrations, not as a source for argumentation. The dwelling place for Hemmingsen's arguments is probably best described as the canon of literature recognized by the learned as legitimate sources of knowledge.

30 "Quare mirabili rursus Dei auxilio adiutus, gloriosas victorias consecutus est: caesis quem una nocte ab angelo DOMINI Assyruriorum, qui urbem Ierosolymam obsidebant, centum octoginta quinquem milibus, inusitatum omnino triumphum egit, habuit quem deinceps regnum pace, opibus, rebus quem omnibus florentissimum.” Bording, Oratio de obitu serenesis, Aii. 
Hemmingsen's topos is of another nature than that of Bording. It is not based on narrations with descriptions of places and is therefore unable to support analogous connections in the way Bording's topos did. Hemmingsen's topos is composed of abstracted knowledge that is easily generalized and transported to new contexts, and which connects flexibly to examples. It is a place expressing a relation not primarily to the history of Israel, but to universal history, and which also contains heathen authors and philosophers. Consequently, it is also a place that is more loosely connected to the oration's main example, King Christian III.

\section{Topography}

In the final part of this analysis, I shall move from the mapping of authorities and patterns of argumentation to the speeches' use of examples, which is their evidientia, their means of proof. Instead of a concept taken from early modern rhetoric, I shall employ the concept of topography as a means to trace how the two rhetorical strategies result in descriptions of places. The speeches hardly contain any topographies in the narrow sense of the word, that is descriptions of landscapes or cityscapes. Nonetheless, the speeches mention names of places connected to narration and description, and when they do, they describe places as ordered by a religious and political reality. This section of the chapter will investigate how these places relate to Jerusalem.

Topography, therefore, does not refer to the orations' patterns of argumentation, but to the elements making up the orations' material, namely their examples. The King and his kingdom is the main example in both orations, with both orators describing the King as ruling his land with both secular and spiritual power, although the topography of his kingdom is to some extent controlled by examples employed to describe the King's rule.

Bording uses descriptions of Jerusalem for this purpose. First he describes it as a cultic place, and then as a place protected by God. Jerusalem's temple was opened, purified, and sanctified, and idolatry was suppressed under King Hezekiah. A narration is tied to this place, when Bording tells of how the King made sure the people turned to the Lord and gathered to celebrate Passover, and how he summoned priests and Levites to maintain responsibility for services in the temple. This description of Jerusalem as a cultic place is then followed by the description of Jerusalem as a city protected by God: because the King had listened to God's counsels, God allowed him to win a miraculous victory over the Assyrians in order to protect Jerusalem from siege. ${ }^{31}$ It is a fairly elaborate topography with descriptions and narrations, which is in turn tied to a parallel topography for Copenhagen.

31 Bording, Oratio de obitu serenesis, Aii. 
Hemmingsen employs a wide range of examples to describe King Christian III's rule, but combines only a few of them with places, and when he does so the descriptions of places are scarce. In one he compares Christian III with Theseus, whom he describes as a benevolent king of the Athenians. ${ }^{32}$ In another the king is described by the example of Moses, who wandered with the people of Israel through the desert and punished the priests when they turned to idolatry. ${ }^{33}$

These two forms of topography, one comprehensive and descriptive of a single place, another scanty and tied to different places, result in different descriptions of Copenhagen and Denmark.

Bording describes Copenhagen as cast in the mould of Jerusalem. With similar words and logic as in his retelling of the story of Hezekiah, he describes the church under King Christian as a version of the temple in Jerusalem. As the temple was cleansed and sanctified, so the church, by the help of powerful preaching, was rid of papist idolatry and reestablished as a pure and united church, with pious rituals and useful and decent ceremonies. ${ }^{34}$ The gathering of priests and Levites, and of treasures to finance temple service, is echoed in a description of the reopened University in Copenhagen, where doctors from the Danish people teach theology and outstanding professors have secure pay, as well as in the establishing of churches and schools on smaller centres as well. ${ }^{35}$

In Bording's topography, Copenhagen is controlled by the same dynamics as Jerusalem under King Hezekiah. The quality of the city's cultic place has direct consequences for domestic and foreign politics. The unity of secular and spiritual rule which Bording's oration aims at, has an implicit basis as seen in the way topography is combined in his two main examples: to be able to protect the country, the King must have power to protect the cult, and in order to be protected, the cult has to be subject to secular authority.

Hemmingsen's topography of Copenhagen has similar motifs, but is structured differently. Copenhagen is not described as parallel to Old Testament Jerusalem, but rather as the place where the King's virtues are displayed. Peace dwells in this place

32 "Neque enim satis est, si Rex in suos fuerit munificus, sed oportet etiam in peregrinos esse liberalem, ut vere de ipso dici possit illud quod in summis laudibus Thesii Regis Atheniensium posuit Euripedes . . ." Hemmingsen, Funebris oratio in memoriam, B2.

33 "Moses idolatram iam factum summum pontificem corripit ac instrumentum idololatriae confingum." Hemmingsen, Funebris oratio in memoriam, B3b.

34 "Sic itaque templum DOMINI aperuit, idemque com Ezechia purgauit \& sanctificavit, cum non sine magnis laboribus \& periculis, multorumque potentum in se conciatis odiis, inuertatam illam multis iam seculis Papisticam idolatriam, penitus sustulit ac profligauit: tandemque quod pater ipsius (piae ac faelicis memoriae) Fredricus I, ferio tentarat, perfecit, vt vera de Deo doctrina, varie prius adulterata, multisque tenebris inuoluta, pura iam \& syncera ecclesiis restitueretur: simulque cum doctrina pii ritus, vtilesque ac decentes cermoniae inttroducerentur." Bording, Oratio de obitu serenesis, Aiii.

35 Bording, Oratio de obitu serenesis, Aiii-B. 
not because God intervenes in a miraculous manner as a consequence of cultic purity, but because the King has kept the peace. By the way he had acquired the Kingdom, the King has displayed a virtue that had served peace, not only because it was a Christian virtue, but because it was in accordance with political wisdom - he had been reluctant to seize power before he had sufficiently broad support throughout the kingdom and had therefore waited until he was requested by the council. ${ }^{36}$ His way of acting does not follow the pattern of Old Testament Kings, but nonetheless expresses the law of the ancients and the wise. According to Cicero, there are certain virtues that make a good regent and avert enemies: wisdom in military affairs, courage, power, good fortune, industriousness in business, strength in dangers, energy in acting, swift accomplishment, and foresight. ${ }^{37}$

Hemmingsen's oration finds support in the vast tradition of philosophers and biblical texts in presenting the King as having both secular and spiritual authority. The rejection of the opposite view, namely that the clergy or the common man should decide in matters of religion correspondingly has the same solid basis. ${ }^{38}$ Hemmingsen describes the King's priority of religious matters as a prominent example of royal virtue and bases the value of such a priority on knowledge extracted from a universal history. Even the profane philosopher Aristotle had clearly seen the necessity for Kings to take responsibility for securing true religion, and Plato had emphasized that a King needed to take responsibility for administering the cult, according to Hemmingsen. ${ }^{39}$ The King had known the value of this rule, since "he had understood that not only his soul's, but also his kingdom's welfare depended on his piety", ${ }^{40}$ and the King's example had shown the practical rationality of this rule. By praying regularly, he came to wish for what was good, and was enabled to move the hearts of his enemies to refrain from their aggressive intents. By

36 Hemmingsen, Funebris oratio in memoriam, Aiiib-Aiiii.

37 Danish translation: "Dette var Begyndelsen af denne priisværdige Konges Regimente, hvori han lod see de Dyder, som Marcus Cicero fordrer hos en god Regent, nemlig: Krigs-Videnskab, Tapperhed, Myndighed, Lykke, Arbeydsomhed i Forretninger, Kiækmodighed udi Farer, Vindskibelighed i at forhandle og Hurtighed i at fuldføre Ting, samt en klog og betænksom Forsynlighed.” Niels Hemmingsen, "Liigtale over den stormægtige Konge I Danmark Etc. Kong Christian III . . ., ” in Den stormægtigste Konge Kong Christian den Tredie, Konge til Danmark og Norge, ed. Niels Krag, vol 1. (Copenhagen: Godiche, 1776), 412; "Hoc fuit auspiciu regni optimi Regis, in quo conspiciuntur virtutes ille, quas Marc Cicero in bono imeratore inquirit, que sunt scientia rei militaris, virtus, authoritas, faelicitas, labor in negotiis, fortitudo in periculis, industria in agendo, celeritas in conficiendo, consiliu in prouidendo." Hemmingsen, Funebris oratio in memoriam, Aiiii.

38 "Plurimum errant omnium sanorum iudicio, qui religionem ad principes haud pertinere arbitrantur, sed de ea debere pontifices statuere \& vulgo prescribere quicquid libet. Nam hoc contra omnium gentium morem, contra Israeliticam politiam, \& contra omnium sanctorum imperatorum \& Regum exempla sacrilege \& impie asseritur.” Hemmingsen, Funebris oratio in memoriam, B3b.

39 Hemmingsen, Funebris oratio in memoriam, B3-B3b.

40 "Nam in vera pietate sitam esse optime nouit, tum anime proprie, tum Reipublice cui prefuit salutem." Hemmingsen, Funebris oratio in memoriam, B4b. 
valuing his subjects' love more than their fear, he had strengthened unity in his realm. ${ }^{41}$ As well, the description of the King's dealings with the Danish church are described within the same logic. The King has secular and spiritual authority not because he is a new version of a biblical King, but as a regent who protects his kingdom according to logic testified to by a learned canon, namely that unity in religion serves a prosperous and peaceful kingdom. A description of Denmark as peaceful and prosperous, unified and without any discord in matters of religion, serves as the final proof for the King's authority and the memory of him as the benevolent protector of religion:

For was there ever greater agreement anywhere in the world in matters of religion, or better discipline and order in the church, than in Denmark? Did ever any heretics let their voice be heard under this Christian King's government? Did ever any useless discussion over religious matters occur? Were ever any Anabaptists or Spirituals housed in this kingdom? For all this we should, next after God, thank our King, who knew that even a tiny bit of sour dough makes the entire dough sour, and that only a small delusion often causes disaster and anger. ${ }^{42}$

Before he thus introduces the example of Denmark as proof, Hemmingsen briefly mentions that which is to be proven, namely the great value of the King's care for religion: "This is shortly noted about our pious prince's second office, as it could be seen in his care for religion ...." This second office was one of the three virtues Hemmingsen initially had claimed that old wisdom demanded of a King. When Hemmingsen towards the end of his speech concludes that the King had embodied this virtue, he uses the term cura religionis, which in the context of

41 Hemmingsen, Funebris oratio in memoriam, B2b-B3.

42 "Atque hec breuiter sint notata de altero officio pii principis, quod in religionis cura cernitur: in quo nullo Regum aut principum totius mundi inferior fuit hic noster Rex \& Pater patrie quemadmodum res ipsa loquitur, \& pii omnes qui ipsum norunt testantur. Nam ubi queso terrarium, tantus in religione consensus? Ubi melior administrande reipublice Ecclesiastice ratio? que unquam heresis hoc sanctissimo Rege gubernante hic est orta? qae aniles disputationes in religione sunt hic mortae? quis Anabaptistis locus? Quae Suermeris sedes? Haec omnia secundum Deum, sanctissima principis cura effect. Sciuit enim prudenter exiguum fermentum totam massam acidam reddere, et minimam erroris labem plurima mala ac scandal accersere.” Hemmingsen, Funebris oratio in memoriam, BiiiibC; in translation: “Og dette maae være nok sagt om vores christeligste Konges anden Pligt, som viiser sig i hans Omhyggelighed for Religionen, hvori han ikke gav nogen Regent og Konge i efter, som han øyensynlig i Gierningen beviiste, og alle Guds Børn, som kiendte ham, bevidne: thi hvor var der vel noget land i Verden, hvor der fantes større Eenighed i Religionen, eller bedre Kirke-Disciplin og Orden, end udi Dannemark? hvor reyste der sig vel noget Kiætterie under denne christelige Konges Regiering? hvor reyste der sig vel nogen unyttig Religions-Trette? hvor blev vel nogen Vederdøber eller Svermer huset her i Riget? alt dette have vi næst Gud vores høyst salige Kongen at takke for, thi han eftertænkte meget viiseligen, at en liden Surdey giør den hele Dey suur, og at en liden Vildfarelse ofte foraarsager Ulykke og Forargelse.” Hemmingsen, "Liigtale over den stormægtige Konge I Danmark." 
early modern theological discourse might hint at how Hemmingsen configures the relationship between church and sovereign. Inge Mager has observed how Luther's doctrine of the two Kingdoms would soon be forgotten among subsequent generations of Lutheran theologians, but that theologians still, especially in sermons, were cautious to reserve a spiritual authority from the secular authority and not to give in to a caesaropapistic or state-churchly logic in their mentioning of the sovereign's authority in the church. They therefore avoided the term "cura religionis", and preferred the term "praecipuum membrum ecclesiae" for the sovereign's role in religious matters. ${ }^{43}$ In Hemmingsen's logic, there seems to be no such reservations. His way of grounding the King's authority in religious affairs is consistent with the term "cura religionis" - the King is not simply the first member of the church, and is not bound by Scripture, but has authority to guard the church for the sake of the common good of his Kingdom.

The topics Hemmingsen draws on enable an even more detailed topography than Bording's oration. It finds its authority not primarily in theology, but in a universal history that among all philosophers and historiographers throughout time also encompasses bible and church. It aims to describe not only how true cult and doctrine are protected, but a society with complete unity because of the King's command of religion. The result is, perhaps, an even more potent promotion of the King's authority in both secular and spiritual matters.

\section{Conclusion}

Both orators treated in this chapter shared the intention of remembering Christian III as the legitimate sovereign over land and church and offering support for future Kings' authority. The analytical concepts employed in this paper have clarified an important difference in how the two speeches offered this support. The Jerusalem code, which is being traced in this book, was clearly at play when Bording preached in Odense cathedral, but not when Hemmingsen spoke to his academy at the University of Copenhagen. In Bording's speech, Jerusalem works topically as an indicator for the choice of the structure of argumentation and as a dwelling place for arguments, and topographically as an example that structures the description of Copenhagen and Denmark. In Hemmingsen's speech, on the other hand, it plays no significant role and is mentioned only implicitly. His speech's topos allows Jerusalem to disappear into the background as one of several examples.

43 Inge Mager, "The Reception of the Two Kingdom Idea in Lutheran Orthodoxy up to Johann Gerhard," in Iustus Ordo e Ordine della Natura. Sacra Doctrina e Saperi Politici fra XVI e XVIII Secolo, ed. Fausto Arici and Franco Todescan (Padova: CEDAM, 2007), 155-72. 


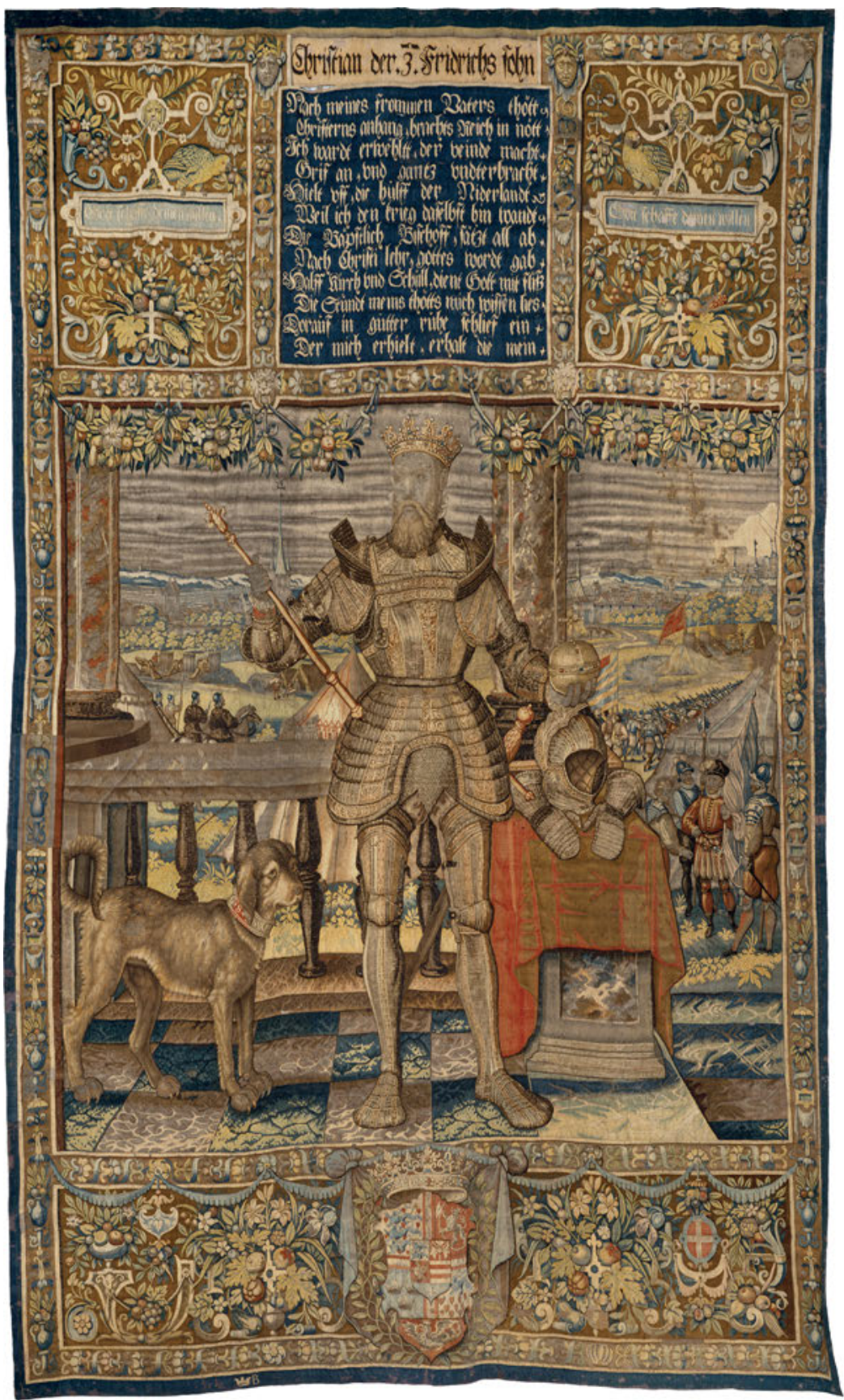

Fig. 6.3: Portrait of Christian III. Tapestry from Kronborg Castle, 1581-84. National Museum of Denmark (Nationalmuseet), Copenhagen. 
The reason for this difference was partly due to a difference of genres, which in Melanchthon's rhetoric meant that they relate to different fields of knowledge with bearings for their choice of loci as the arguments' dwelling places, or as material topoi. ${ }^{44}$ As Bording's oration was a sermon, it used theology as its field of knowledge and found its loci in the Holy Scriptures. ${ }^{45}$ Conversely, Hemmingsen's speech at the University seems to have been related to philosophy as its field of knowledge, for here arguments could be drawn from all aspects of human life. ${ }^{46}$ This is confirmed when one compares the many classical funeral sermons Hemmingsen presented in churches and in which he almost entirely derives his arguments from the bible. ${ }^{47}$

An important difference was also found in the way the orators employed patterns of argumentation, that is their formal loci or topoi, which is independent of genre. Hemmingsen was closest to the ideal prescribed by Melanchthon and repeated in his own book on method, ${ }^{48}$ namely that an argument should move from hypothesis to thesis, and from specific to general sentences - in other words, that narration should serve abstract propositions. ${ }^{49}$ Bording's arguments remained to a greater extent on the level of narration, since they did not target general truths, but argued through descriptions that were connected to each other by resemblance as types and antitypes - the bible story and its examples present God's action, and when contemporary occurrences repeat this story, the two stories together display how God is acting in the present. This argumentative ideal was also expressed in many German Lutheran funeral sermons, ${ }^{50}$ and rested on traditional homiletic practice, ${ }^{51}$ but was

44 "Ac voco locos communes, non tantum virtutes et vicia, sed in omni doctrinae genere praecipia capita, quae fontes et summam artis continent." Philipp Melanchton, "Elementa Rhetorices. Grundbegriffe Der Rhetorik,” ed. Volkhard Wels (Berlin: Weidler Buchverlag, 2001), 83, 138.

45 "Docenti in Ecclesia, certa materia in sacris literis praescripta est, quam explicare debet." Melanchton, Elementa Rhetorices. Grundbegriffe Der Rhetorik, 67, 123.

46 "Ac philosophici possunt peti ex partibus hominis, ratio, artes, prudentia, virtus, affectus, consuetudo, corpus, forma, aetas, fortuna, divitiae, oeconomia, coniugium, educatio, liberorum, politia, magistratus, lex, bellum, pax.” Melanchton, Elementa Rhetorices. Grundbegriffe Der Rhetorik, 84, 139. 47 Niels Hemmingsen, En Predicken . . . Herluf Trolle Ridders Begraffuelse (Copenhagen: Laurentz Benedicht, 1565); Niels Hemmingsen, En Predicken, ... Maagens Gyldenstiernis Begraffuelse (Copenhagen: Matz Vingaard, 1570); Niels Hemmingsen, En Predicken . . Otte Ruds Begraffuelse (Copenhagen: Matz Vingaard, 1571).

48 Hemmingsen, De Methodis.

49 "Addemus autem ad inventionis praecepta unum quod maximam vim habet in omnibus disputationis, videlicet, ut hypothesin transferamus ad thesin. . . . Facile autem iudicare potest, cum de Turcico bello dicendum est, omnia plniora atque uberiora fore, si a specie ad genus oratio transferatur, et de magistratus officio, de bello in genere dicatur, quam pium, quam sanctum officium reges faciant, si has gentes divinitus ipsorum tutelae comissas, adversus Turcicum latrocinium defendat." Melanchton, Elementa Rhetorices, 82, 128.

50 Angel, The Confessionalist Homiletics of Lucas Osiander (1534-1604), 67-138.

51 Stuart Georg Hall, “Typologie,” in Theologische Realenzyklopädie, ed. Gerhard Müller (Berlin: de Gruyter, 2002), 214-16; Suntrup, “Typologie”. For an elaborate description of this homiletic strategy see Felix Bidembach, Manuale ministrorum ecclesiae (Leipzig: Henning Grossen, 1619). 


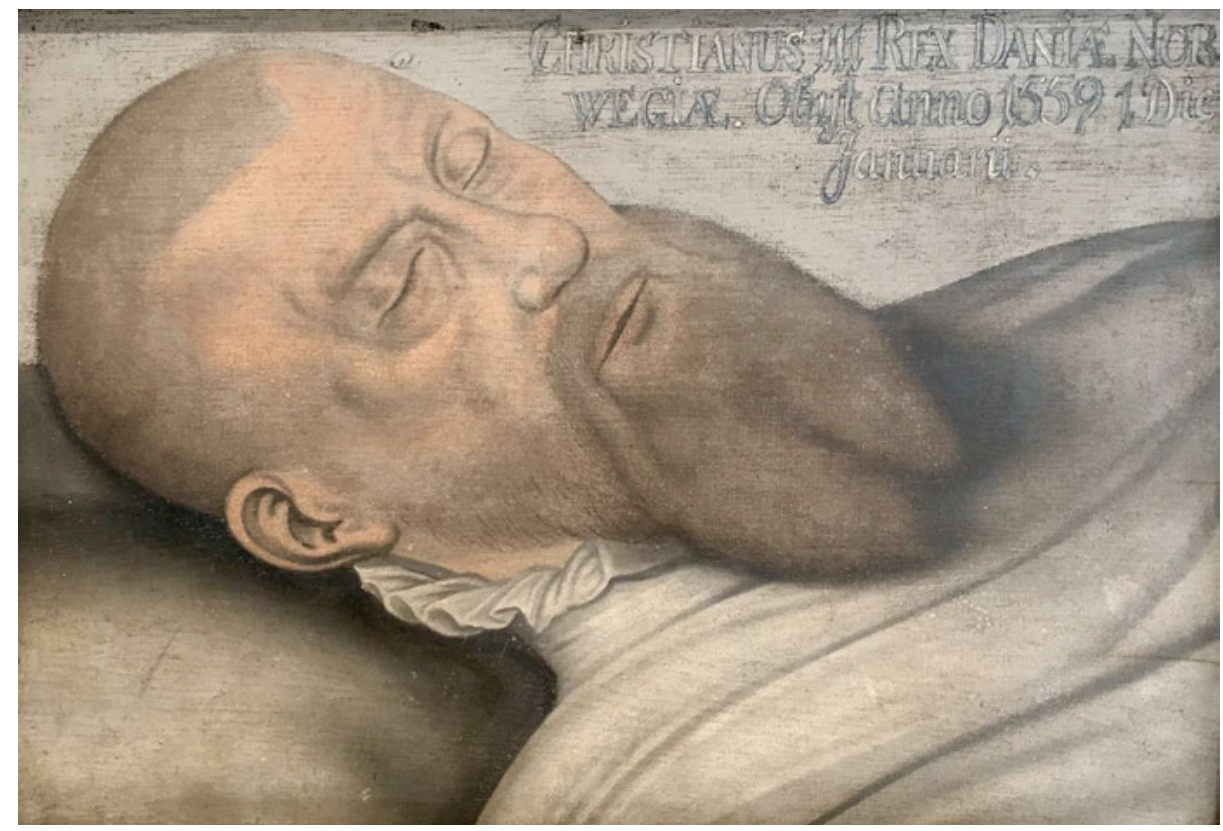

Fig. 6.4: Portrait of the deceased King Christian III. Copy of an original painting ascribed to Jost Verheiden. Malmø Kunstmuseum, Sweden.

different from that of Hemmingsen. The topoi Hemmingsen drew on corresponded to the knowledge culture of the university. However, since Hemmingsen's Postil express a clear Melanchthonian ideal for inventio and argumentation, one may assume that this represented the rhetoric encouraged in preaching, as well as the knowledge culture expressed on pulpits. $^{52}$

The rhetorical strategies displayed in these two sermons anchor authority differently and may be described as different political actions. In Bording's speech, which has clear resemblances to German Lutheran funeral orations, the King's authority rests on the biblical story as it is interpreted and narrated by the preacher, and its logic relies on salvation history. It offers a view of society in which types from biblical history give premises for how a good King might be portrayed, and confessional characteristics are decisive for the turn of history. Thus, the Jerusalem code supports the King's power over religion, but also binds him to the biblical story. Hemmingsen's speech targets a very wide, learned field of knowledge. Its theological profile is less sharp, but its political message and description of the King and his kingdom are all the more precise. When the speech seemingly employs

52 Niels Hemmingsen, Postilla eller Forklaring offuer Euangelia (Copenhagen: Gutterwitz oc Stöckelsmands Arffuinge, 1576). 
all the stories which make up universal history to give the grounds for the King's authority over religion, it portrays the King with an authority that rests not on resemblance with biblical types or a preachers' scriptural interpretation, but rather frees the King to employ religion for higher means as cura religionis. This is a form of funeral oratory which, to my knowledge, is not found among German Lutherans of that day. Perhaps this form of portrayal was enabled by the fact that Christian III was a King and not a prince as were his fellow sovereigns in Germany. He therefore did not have to consider Imperial Law and its protection of a relative independence of church restrictions on territorial princes' injunctions. ${ }^{53}$ Øystein Rian has argued that Christian III's rule meant a greater concentration of power than in most other countries, when diverse independent institutions were outmaneuvered and subjected to the king, with most prominent of them being the church. ${ }^{54}$ Although Christian III was not an absolutist monarch, one might see Hemmingsen's rhetoric prefiguring the absolutism introduced in $1660 .{ }^{55}$

The two rhetorical strategies in the two speeches not only supported the King's authority by different means, they also lent him differing types of support. In Bording's speech, the King followed a biblical pattern, while Hemmingsen showed him as embodying eternal virtues. Bording painted the King's memory in a way that united King and cult, whereas Hemmingsen allowed him to subjugate the cult for the well-being of his Kingdom. Thus, these royal orators show that the Jerusalem code operated within limits. It worked within the church, but not when a King asserted power over the church.

53 Siegrid Westphal, “Zur Erforschung der Reichsgerichtsbarkeit - eine Zwischenbilanz," Jahrbuch der historischen Forschung (1999).

54 Rian, Sensuren i Danmark-Norge, 331.

55 Joar Haga, "Gerhard (Un)Seen from Copenhagen? Danish Absolutism and the Relation between State and Church," in Konfession, Politik und Gelehrsamkeit. Der Jenaer Theologe Johann Gerhard (1582-1637) im Kontext seiner Zeit, ed. Markus Friedrich, Sascha Salatowsky, and Luise SchornSchütte (Stuttgart: Steiner, 2017). 
